\title{
GEOLOGY
}

UDC 553.07

M.A. Mizernaya ${ }^{1}$, Cand. Sc. (Geol.-Min.), orcid.org/0000-0001-8618-7352,

S.S. Aitbayeva ${ }^{1}$, orcid.org/0000-0003-0285-0773, A. I. Mizerny ${ }^{1}$, orcid.org/0000-0003-2445-4130, B. A. Dyachkov ${ }^{2}$, Acad. of the NSA of RK, Dr. Sc. (Geol.-Min.), Prof., orcid.org/0000-0002-5956-7496, A. P. Miroshnikova ${ }^{3}, \mathrm{PhD}$, orcid.org/0000-0002-2710-7049 https://doi.org/10.33271/nvngu/2020-1/005

1 - D. Serikbayev East Kazakhstan State Technical University, Ust-Kamenogorsk, the Republic of Kazakhstan, e-mail: mizernaya58@bk.ru

2 - LLP "Altaiskiy Geologic-Ecological Institute", Ust-Kamenogorsk, the Republic of Kazakhstan, e-mail: bdyachkov@ $\underline{\text { mail.ru }}$

3 - "VNIItsvetmet", Affiliate of RSE "NC CPMRM RK", Ust-Kamenogorsk, the Republic of Kazakhstan, e-mail: anastasiya-2588@mail.ru

\section{GEOCHEMICAL CHARACTERISTICS AND METALOGENY OF HERZIN GRANITOID COMPLEXES (EASTERN KAZAKHSTAN)}

Purpose. To find out regularities of formation and spatial distribution of new non-conventional types of rare metal mineralization, to develop forecasting and search criteria and to evaluate perspectives as an additional reserve for strengthening and developing East Kazakhstan region mineral resources base.

Methodology. Using ICP MS methods at D. Serikbayev EKSTU Advanced Development Center, there are studied conventional and unconventional plays and occurrences of rare-metal mineralization within the Western Kalba and Rudny Altai, magmatites of Kalba-Narymsky rare-metal granitoid belt. Study on chemical composition of magmatites of a number of intrusive complexes was carried out, the relation of the granitoids with rare metals deposits and manifestations was established. A comparative characteristics of ore mineralization in studied deposits was carried out by scanning electron microscopy (JSM 6390LV).

Findings. Magmatic complexes of potential various rare-metal mineralization within the Kalba-Narym granitoid belt (East Kazakhstan) were identified; conclusions about the relation of potential ore content with granites of certain formation types were made.

Originality. It is established that along with the conventional rare-metal type within the Kalba-Narym metallogenic belt there are found non-pegmatitic unconventional manifestations of rare-metal mineralization of $\mathrm{Nb}, \mathrm{Li}, \mathrm{Sn}$. Rare-metal pegmatitic ores with the increased content of $\mathrm{Li}, \mathrm{Ta}, \mathrm{Nb}$, as well as greisen-silica-veined manifestations of $\mathrm{Sn}, \mathrm{W}$ and gold ore sites with with the increased content of rare elements are to be prospective. The high content of rare metals and rare earth in ores of gold ore deposits of the Western Kalba and Rudny Altai was established.

Practical value. The obtained data can be used for rare metal deposits and complex gold-rare metal deposits prognosis and prospecting.

Keywords: Hercynian magmatism, deposits, rare metals, Kalba - Narym rare metal belt, Kazakhstan, resources

Introduction. Current requirements to the resources of some critical types of raw materials enable to take a fresh look at the approach to studying deposits. The development of analytic base, appearance of some new modern highly-precise methods for studying chemical and mineral composition of ores and enclosing rocks created prerequisites for changing research methodology and economic-geological evaluation of deposits $[1,2]$.

The given paper is devoted to analyzing the problem of Hercynian magmatism in the East Kazakhstan and to finding out regularities of complex conventional and unconventional deposits of rare metal formation.

Unconventional sources of rare metals have come under scrutiny of many scientists (Korobeinik, 1999, 2004; Bykhovsky and others, 1999; Potseluev, 2014). Under conditions of price and demand rise, this objects can become sources of concurrent recovery of precious components, due to develop-

(C) Mizernaya M.A., Aitbayeva S.S., Mizerny A.I., Dyachkov B.A., Miroshnikova A. P., 2020 ment of rational technologies for recovery of valuable elements [3]. For example, high concentrations of rare metals have been found at many proper gold ore and pyrite-polymetallic deposits of Africa (Witwatersrand, the Republic of South Africa), Australia (Olimpia, Dem), Uzbekistan (Muruntau), Kazakhstan (Yubileinoe, Vasilkovka, Ridder-Sokolnoye) and others. On the other hand, high concentrations of precious metals are found in many large rare metals deposits of the world (Kosachinnoe, Chaglinka, North Kazakhstan), Oyu Tolgoi (Mongolia) and others. Factors of similar complex deposits, finding out criteria for their prospecting and evaluation are the basic tasks of modern prognostic-prospecting technologies development [4]. The territory of East Kazakhstan is a part of Great Altai that comprises Hercynian structures of the Rudny Altai, Kalba (the Kalba-Narym belt, the West-Kakba belt) and Zharma Saura. Line (belt) distribution of precious, non-ferrous and rare metals deposits was find out within these structures. The Rudny Altai mainly has gold-copper-polymetallic trend. Basic gold-ore deposits [5] are concentrated in the West-Kalba belt. Leading rare metal structure of the Great Al- 
tai is the Kalba-Narym rare metal belt. According to the data provided by M.S. Rafailovich, more than $70 \%$ of accounted $\mathrm{Ta}$ and $\mathrm{Nb}$ reserves of Kazakhstan are concentrated here [1,6].

The territory of East Kazakhstan is a part of the Greater Altai which unites the Hercynian structures of the Rudny Altai, Kalba-Narym, Western Kalba and Zharma Saur. A linear (belt) distribution of precious, non-ferrous, and rare metal deposits has been identified within these structures. The KalbaNarym rare metal belt is a leading rare metal structure of the Big Altai. According to M.S. Rafailovich (2011), more than $70 \%$ of $\mathrm{Ta}$ and $\mathrm{Nb}$ reserves in Kazakhstan are concentrated here $[1,6]$.

Characteristics of Hercynian magmatic complexes. Peculiarities of Hercynian magmatism and its connection with occurrence of rare metal and gold-rare metal mineralization have been studied in the works of the given stage. Hercynian magmatism was powerful and very uneven within the eastern part of Kazakhstan. Metallogeny of this period is characterized by wide variety of mineral and geological-industrial types of deposits. Early stage of Hercynian cycle of East Kazakhstan is evident in the Rudny Altai and Zharma Saur by island-arc basalt-andesitic volcanism and by accompanying gold-copper-polymetallic mineralization (Ridder-Sokolnoye, Artemyevckoe, Nikolaevskoe and other deposits).

During the medium stage, crust-mantle magma intrusion took place along the fault array and at selvages of continental margins. Magmatite-gneissic and gabbro-plagiogranite intrusions of Irtysh Land series, $\mathrm{C}_{1}$ were formed in the Irtysh zone. Large multiple phase plutonic intrusions of gabbro-dioritegranodiorite-plagiogranite series and gold-sulphide mineralization (Sekisovskoe deposit) connected with them manifested in the Zharma-Saur and Rudny Altai [5, 7].

Rare metal deposits were formed mainly in the Late Hercynian stage of postcollisional (orogenic) intraplate activation, accompanied by a powerful manifestation of granitoid magmatism typical for many Central Asian regions [2]. Spatially, they are located in large granitoid belts of considerable length (up to $800 \mathrm{~km}$ ). The example of such a long belt in East Kazakhstan is the Kalba-Narym rare metal belt [8].

Magmatic processes are widely manifested in the West Kalba. There is paragenetic connection of many veined fields with these processes. The fields are located in the over- and near-intrusive zone or directly within minor granitoid massif outshots. Intrusives of Kunush gabbro-plagiogranite series $\left(\mathrm{C}_{3}\right)$ are most widely spread. They are represented by minor bodies of amphibolized gabbro-diabases, biotite tonalities, plagiogranites. According to their petrochemical characteristic properties, they are considered as rocks with high sodium content of high alumina and low total alkali. Besides intrusives of Kunish complex, there is a gabbro-diorite dyke complex in some gold ore fields. It builds up strong north-west and eastwest trending belts. The complex comprises wide spread lamprophyric dykes (spessartites), subalcalic gabbrides, highly sodium dioritic porphyrites, eruptive breccia. High $\mathrm{TiO}_{2}$ concentrations (up to $2.21 \%$ ) and $\mathrm{P}_{2} \mathrm{O}_{5}$ (up to $0.89 \%$ ) are characteristic for the rocks of the complex.

Rafailovich M. S. referred gold-sulphide deposit of black shale type Bakyrchik to large gold-tungsten deposits of Kazakhstan that are located in the West-Kalba gold-ore belt.

According to geophysical data, there is intrusive massif $(7 \times 3 \mathrm{~km})$ of gabbro-diorites in Kyzyl fault zone directly below Bakyrhik ore zone. Many authors refer this massif to collision granodiorite-plagiogranites of Kunush complex $\left(\mathrm{C}_{3}\right)$. The differentiates of the intrusive complex of Bakyrchik are located in layers: the granitoid chamber occurs at depths between $3.0-3.5 \mathrm{~km}$, and dyke rocks are localized on the upper level in the ore-bearing overlap fold zone [9].

Gold bearing carboniferous-aleuropelitic levels together with idiogenous gold-pyrite mineralization are associated with terrigenous deposits (Bakyrchik black - shale rock mass $\mathrm{C}_{3}$ ). Above-background gold is up to $100-150 \mathrm{mg} / \mathrm{t}$.
Ore bodies (average gold content is $9.4 \mathrm{~g} / \mathrm{t}$ ) were exposed at the depth of 1000-1500 m. Structures that localize mineralization are identified by geophysical methods at the depth of $3000 \mathrm{~m}$. Ore bodies are lenticular, ribbon-, and lens- shaped subconcordant crushed veins, associated with intersection nodes of Kyzyl shear zone faults [1].

The basic valuable element is gold. Au content is dozens, more frequently hundreds $\mathrm{g} / \mathrm{t}$ in pyrites. There is increased $\mathrm{Ag}$ content (up to $5 \mathrm{~g} / \mathrm{t}$ ). Ores contain up to $1.5 \%$ of copper, molybdenum, tungsten, bismuth - a hundredth of a percent. Gold, tungsten and other elements distribution is characterized by vertical zonality.

The general feature for all gold deposits in black-shale rock mass (Muruntau, Kumtor and others) is high content of tungsten and other rare metals due to late gold-quartz-carbonatescheelite-chalcopyrite-molybdenum mineralization. Volframite share in ores of Kumtor deposit is from 0 to $30.4 \%$, impurities content in calcium tungstate in $\mathrm{g} / \mathrm{t}$ is $\mathrm{Sc} 20-300$; La 500-1000; Sr 30 000; Mo 10-1000; Y 100-6000; Yb 400. The content of rare and rare-earth metals in Muruntau scheelites in $\mathrm{g} / \mathrm{t}$ is Y 100-6000; Nd 250; Ce 190-350; Eu 2-130; Sr 400-1100; Lu 0.5-4.0; Sm 20-90. Gold and rare metals paragenesis at Bakyrchik deposit has not been studied well enough. However, rare metals and rare earths have been found in the ores of the deposit by L. G. Marchenko (W, Mo, Sn, Y, Ce, $\mathrm{Ga}, \mathrm{In}, \mathrm{Ta}, \mathrm{Yb}, \mathrm{Er}, \mathrm{La}$, etc.). Scheelite concentrate can be considered as a source of tungsten and rare earth, molybdenum, bismuth. Medium and upper levels of Bakyrchik deposit are productive for gold, and tungsten content increases with depth. Tungsten mineralization at such deposits is of great interest as it can be the source for recovering numerous valuable elements (rare metals and rare earth). These elements increase margins of their mining. Processing products (gravity concentrates of gold-sulphide ores) are also supposed to be the source of tungsten [1].

The Permian granitoid formations of the Kalba-Narym belt vary in age, material composition, type of rare-metal mineralization [10]. The chemical composition, concentration of the main and dispersed elements of the main igneous complexes were determined by ICP-MS methods. An almost constant $\mathrm{Al}_{2} \mathrm{O}_{3}$ content (mass \%) on average 15.6 (up to 13.7 in leucogranites) was established for the entire range of granitoids. The sum of $\mathrm{K}_{2} \mathrm{O}$ and $\mathrm{Na}_{2} \mathrm{O}$ is different for all complexes with a predominance of potassium over sodium in most complexes $\left(\mathrm{K}_{2} \mathrm{O}\right.$ and $\mathrm{Na}_{2} \mathrm{O}$ from 6.4 to 8.4), except for the plagiogranites of the Kunush complex $\left(\mathrm{K}_{2} \mathrm{O}(1.11)<\mathrm{Na}_{2} \mathrm{O}(5.26)\right)$. The amount of $\mathrm{CaO}$ and $\mathrm{MgO}$ is minimal (1.23-1.49) for muscovitized granites of phase II and leucogranites of the Monastyrsky complex; it rises for granites of phase II (2.67) and is the highest (3.37) for plagiogranites of the Kunush complex. The sum of $\mathrm{FeO}$ and $\mathrm{Fe}_{2} \mathrm{O}$ in whole remains practically unchanged for all complexes $(2.4-2.6)$ with the exception of (3.5-4.1) granites of the $1^{\text {st }}$ phase of the Kalbinsk complex. The ratio of $\mathrm{CaO} / \mathrm{MgO}$ varies slightly.

A petrochemical diagnostics diagram of rocks $\left(\mathrm{Na}_{2} \mathrm{O}+\right.$ $\left.+\mathrm{K}_{2} \mathrm{O}\right)-\mathrm{SiO}_{2}-$ TAS (Coxetal, 1979) (Fig. 1, $a$ ) shows the concentration of rocks of all the complexes in the field of granites and partially granodiorites. In the aggregate of petrological parameters, the rocks of all the complexes belong to subalkaline, high potassium ones, with the exception of dikes of the Kunush complex, which fall into the field of normal series (tholeitic series) Figs. 1, $b, c$. From the diagram of A/CNK to $\mathrm{A} / \mathrm{NK}$ it can be seen that all the complexes are located in the region of supersaturated alumina rocks.

According to the results of ICPMS chemical analyzes obtained in Irgetas engineering laboratory at D. Serikbayev EKS$\mathrm{TU}$, spidergrams of trace elements and distribution charts of rare-earth elements for all studied igneous complexes were built. From the analysis of the spidergram of trace elements normalized by the primitive mantle (Wood et al. 1979) Fig. 2, $a$, it is clear that, in general, the distribution pattern of 

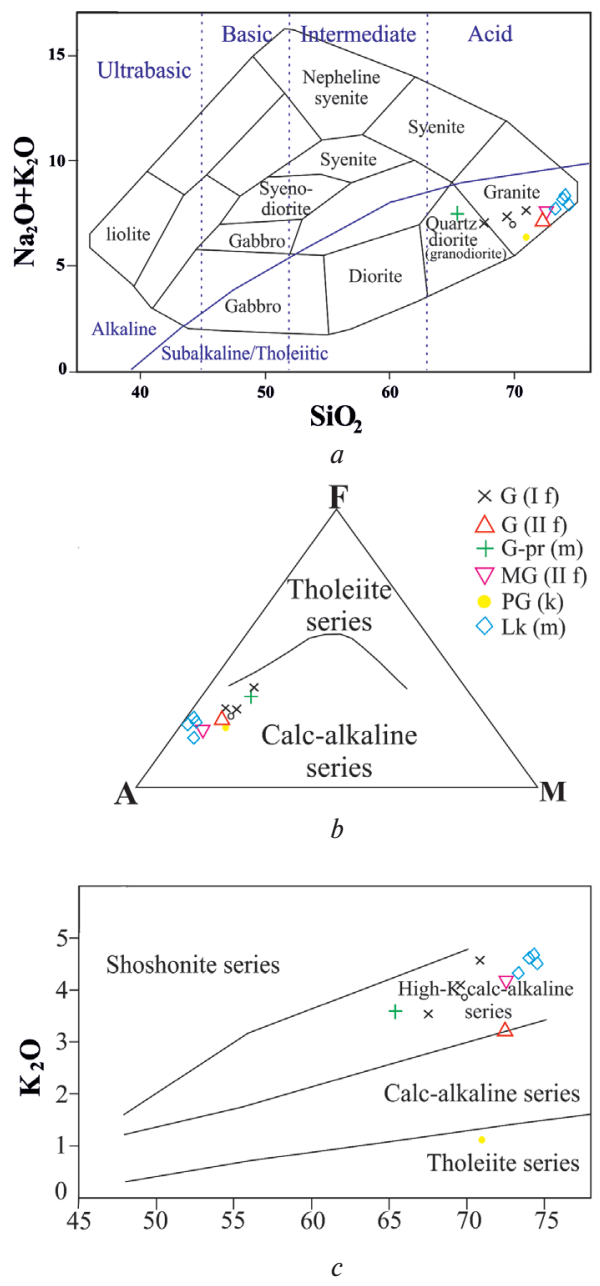

Fig. 1. Diagrams:

$a$ - TAS plot: $\left(\mathrm{Na}_{2} \mathrm{O}+\mathrm{K}_{2} \mathrm{O}\right)-\mathrm{SiO}_{2}$ (LeBas et al. 1986) with a line dividing rocks into alkaline and sub-alkaline (Irvine and Baragar, 1971); $b$ - AFM plot (Irvine and Baragar, 1971); $c$ $\mathrm{K}_{2} \mathrm{O}-\mathrm{SiO}_{2}$ plot (Peccerillo \& Taylor, 1976)

the trace elements has a general trend, which indicates a similar enrichment - depletion pattern of the elements.

The spidergram of scattered elements (Fig. 2,a) of all magmatite complexes shows clearly pronounced negative anomalies of $\mathrm{Pr}, \mathrm{Ce}, \mathrm{La}, \mathrm{Nb}, \mathrm{Ba}$; to a lesser extent of Ti. The leucogranites curve of the Monastyrsky complex indicates that depletion of $\mathrm{Ce}, \mathrm{La}$ is much lower compared to other complexes, yet significant (10 times) for Ti, P, Sr. A negative anomaly of Ti is also characteristic of Kalbinsky complex muscovitized granites of phase II. A significant $\mathrm{Cs}, \mathrm{Pb}$ concentration in rocks of all magmatic complexes is observed: $\mathrm{K}, \mathrm{Th}, \mathrm{U}$, Ba concentration and other large litofil's elements to a lesser degree. Positive $\mathrm{Nd}$ anomalies are observed in leucogranites of the Monastyrsky complex except for those listed above. The presence of positive $\mathrm{Cs}, \mathrm{U}, \mathrm{Pb}$ and negative $\mathrm{Nb}, \mathrm{P}, \mathrm{Ti}, \mathrm{Yb}$ anomalies is characteristic of Kunush plagiogranites.

The pattern of rare-earth elements distribution in Kalbinsk complex granites of I and II phases (Fig. 3, $b$ ) has a similar element distribution trend being practically in a single field; the overall negative slope of the curves with a significant predominance of light elements over heavy ones. A slight enrichment of $\mathrm{La}, \mathrm{Pr}, \mathrm{Gd}$ is detected in rocks of both phases. An inexplicit negative europium anomaly is detected in phase I granitoids, and a slight $\mathrm{Tm}$ anomaly is detected in phase II rocks.

The spectrum curve of the Kalbinsk muscovitized granites of phase II has a gentler slope and low rare-earth elements concentrations, with light elements predominating over heavy
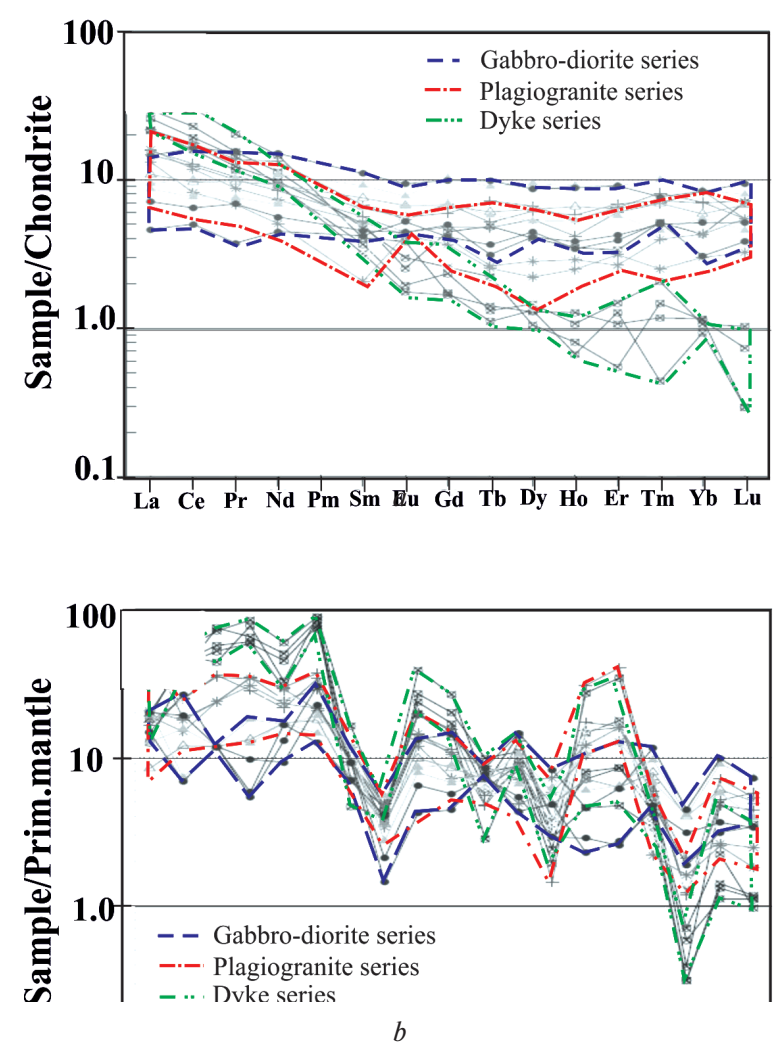

Fig. 2. Spidergrams of trace elements (a) and distribution charts of REE (b) of the Kalba Narym belt, conditional as in Fig. 1

ones. A weakly pronounced negative Ce anomaly and a pronounced negative Eu anomaly are observed. The Monastyrsky leucogranites have a general trend for the rare-earth elements curve slope similar to the Kalbinsk granites which contain the rare-earth elements; they have a distinct Eu anomaly. The spider plot of the Kunush granodiorites shows a significant predominance of light rare-earth elements over heavy ones, which is expressed by a sharply negative field of the distribution curves; there are almost no negative or positive anomalies.

The issue of the age of the Kalba-Narym granitoids is adequately covered in the literature; correlation schemes and the sequence of formation of magmatic complexes were compiled in different years. The basis of the correlation is general geological data and isotope datings for zircons $(\mathrm{U}-\mathrm{Pb})$, biotite (K-Ar) amphibole $\left(\mathrm{Ar}^{40} / \mathrm{Ar}^{3}\right)$ [12]. It was found that the total time of formation of magmatites is about 100 million years. The age of igneous complexes is shown in the Table.

Sekisovskoe gold-sulphide deposit of stockwork type was studied as additional reserve of new unconventional type of rare metals mineralization in accordance with the goal of these research studies and directions of search and assessment. The deposit is located within Shemonaikha-Narym lineation, identified

Table

The age of the Kalba-Narym igneous complexes [13]

\begin{tabular}{|l|l|c|l|}
\hline \multicolumn{1}{|c|}{$\begin{array}{c}\text { Era, } \\
\text { age }\end{array}$} & $\begin{array}{c}\text { Granitoid } \\
\text { complex }\end{array}$ & $\begin{array}{c}\text { Age, mln (PD } \\
\text { Kotler et al., 2015) }\end{array}$ & Mineralization \\
\hline $\mathrm{C}_{3}$ & Kunushsky & $295 \pm 2.0-306 \pm 9.0$ & $\mathrm{Au}, \mathrm{Ag}, \mathrm{As}$ \\
\hline $\mathrm{P}_{1}$ & $\begin{array}{l}\text { Kalbinsky I } \\
\text { phase }\end{array}$ & $290 \pm 3.0-300 \pm 3.0$ & $\mathrm{Sn}, \mathrm{W}(\mathrm{Li}, \mathrm{Be}, \mathrm{Ta})$ \\
\hline $\mathrm{P}_{1}-\mathrm{P}_{2}$ & $\begin{array}{l}\text { Kalbinsky II } \\
\text { phase }\end{array}$ & $289 \pm 3.0-275 \pm 3.0$ & $\mathrm{~W}, \mathrm{Sn}(\mathrm{Ta}, \mathrm{Li})$ \\
\hline $\mathrm{P}_{2}$ & Monastyrsky & $285 \pm 3.0-271 \pm 3.0$ & $\mathrm{~W},(\mathrm{Sn}, \mathrm{TR})$ \\
\hline
\end{tabular}


according to the data from space images interpretation. They are located inside the north-west part of Sekisovka ring structure.

Ore mineralization is associated with gabbro-dioritegranodiorite-granite Sekisovka multiphase massif of Zmeyinogorsk complex $\left(\mathrm{C}_{3}\right)$. Massif area is about $100 \mathrm{~km}^{2}$. Magmatites are localized in igneous-sedimentary rocks $\left(\mathrm{D}_{3} \mathrm{fm}-\right.$ $\mathrm{C}_{1}$ ). Igneous rocks of Sekisovka massif can be divided into 2 series (gabbro-diorite and plagiogranite), main and acidic postgranite dykes control basic ore mineralization (Figs. 3, $a$, b) [14].

Both series have similar indicators of concentration and depletion of rare elements (they are rich in $\mathrm{K}, \mathrm{Zn}, \mathrm{Pb}$, and depleted in $\mathrm{Nb}, \mathrm{P}$ and Ti) (Fig. 4, $a$ ). Cabbro-diorite series demonstrate a planar structure of rare earth elements with weak Eu anomaly and low concentration of light rare earth elements in comparison with heavy rare earth elements. Peaks from granite porphyrites illustrate various behavior of rare earth elements with strong concentration in light rare earth elements in comparison with heavy rare earth elements and small negative or even positive $\mathrm{Eu}$ anomalies (Fig. 3, $b$ ).

There are zones of multiphase explosive-hydrothermal breccia in the north-east part of the massif. The deposit ore bodies are concentrated within complicated hydrothermal breccia. They are pipe-shaped, tapered towards the bottom; their size is from 40 to $120 \mathrm{~m}$ in diameter. Their tracked depth is from 100 to $900 \mathrm{~m} \mathrm{[15].} \mathrm{According} \mathrm{to} \mathrm{mineral} \mathrm{composition,}$ there are four types of ore-bearing breccia (mixed, main and acidic). Mixed breccia is most of all rich in gold ore.

Gold is contained in sulphides (mainly pyrite, less often chalcopyrite, galenite, sphalerite). Gold and silver tellurides, as well as bismuth minerals are widely developed $[1,15]$. Free gold is less spread and localized in quartz-carbonate veins within bodies and breccia cement.

There are two mineral parageneses for gold-sulphide ores. Early breccia, spread mostly at intermediate and deep levels of the deposit, are characterized by gold-iron-copper-rare metal paragenesis and predomination of gold minerals, magnetite
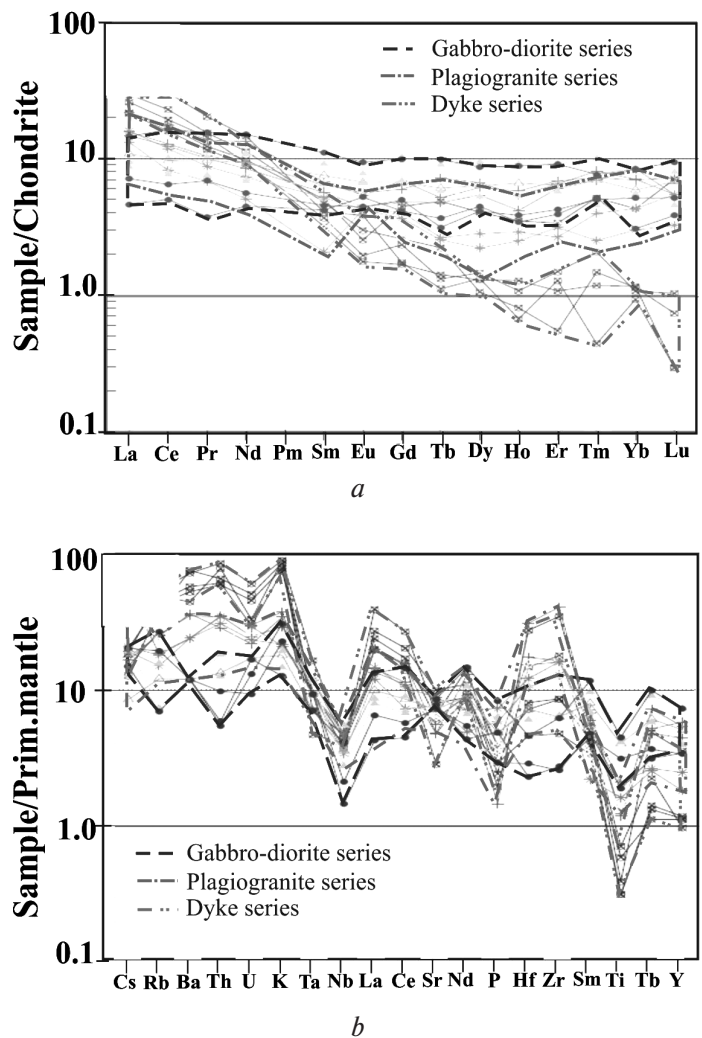

Fig. 3. Spidergrams of rare (a) and (b) rare earth elements of host granitoids from Sekisovskoe deposit quartz, pyrrhotine, pyrite, marcasite, bismuthine, molybdenite, scheelite (Fig. 4).

The late stage of deposit formation and mixed breccia emersion is characterized by gold-silver-bismuth-tellur polymetallic association. The characteristic minerals of this association are gold II, native silver, lead and gold tellurides, quartz, different carbonates, pyrite of several generations, chalcopyrite, bismuth minerals, galenite, sphalerite and others. Late mineral association is controlled by dykes of quartz albitophyres, granite- and felsite- porphyries [1]. Free gold, and gold contained in tellurides and in the form of fine-dispersed impurities in sulphides predominate. The average

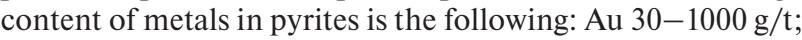
Bi 300-400 up to $1000 \mathrm{~g} / \mathrm{t}$; Mo up to $1 \mathrm{~g} / \mathrm{t}$. There are increased contents of rare and rare-earth elements in the changed enclosing rocks and ore breccia, g/t: (W up to 1; Te $0.3-0.4$; Sn 13.5; Rb 26.1-59.64; Nb 1.9-5.7; Cs 2.5; Nd 5.2-18.7; Y 5.4-35.7; Sr 65.0-200.0; Sm 1.7-3.13; Th 0.4-0.9) (Fig. 4).

When mixed type breccia was formed at the late stage, gold-silver-bismuth-tellurium-polymetalic association was deposited (with gold II, native silver, telluride, quartz, carbonates, pyrite, chalcopyrite, altaite, aikinite, tennantite, galenite, sphalerite, greenockite, tellurobismuthite, petzite, hessite, crednerite, calaverite, sylvanite) at the upper levels of breccia bodies. This association is controlled by dykes of quartz albitophyres, granite-porphyries, and felsites. Quartz-carbonate and quartz- sulphide veins predominate. Gold is in free form as tellurides and fine-dispersed impurities in sulphides. Pyrites contain Au 30-1000 g/t; Bi 300-400 up to $1000 \mathrm{~g} / \mathrm{t}$; Mo up to $1 \mathrm{~g} / \mathrm{t}[1,14]$.

It can be seen that besides gold, rare metal mineralization predominate at gold-sulphide stockwork deposits. It should be taken into account in further assessment works and in ore concentration technology. Baladzhal deposit is referred to goldsulphide stockwork deposits in the West Kalba. It is necessary to continue to study ores of this deposit.

Discussion. The ore-bearing granitoid magmatism of Kalba and adjacent areas was estimated based on the system analysis of geotectonic, geological, structural, petrological, mineralogical and geochemical characteristics and criteria that are indicators of the metallogenic specialization of certain geochemical environments and ore-magmatic systems. The cyclically-directed evolution of the Late Paleozoic magmatism is emphasized, which is fixed by a consistent series of specific magmatic complexes and phases with different ore-bearing properties.

The collision ore-magmatic system uniting the near-fault belts of the hypabyssal minor intrusions and dikes of granodi-
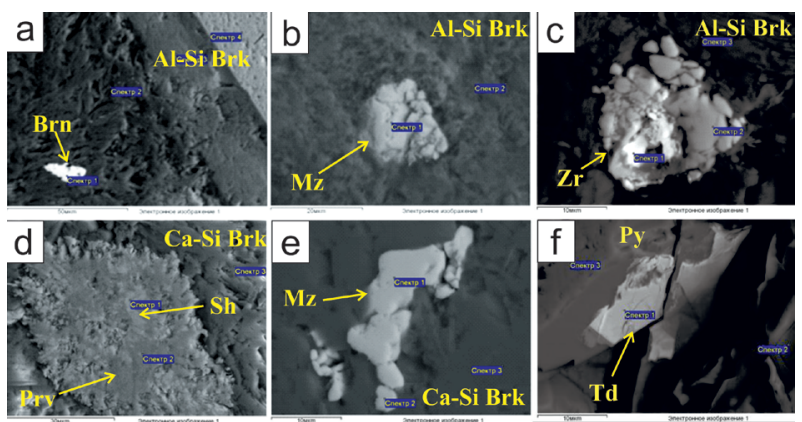

Fig. 4. Minerals of rare metals and rare earth in ore-bearing breccia of Sekisovskoe deposit:

$a$ - brannerite (Brn) in breccia cement aluminosilicates (Al-Si Brk); $b$ - monocyte $(\mathrm{Mz})$ in breccia cement aluminosilicates (Al-Si Brk); $c$ - zircon ( $\mathrm{Zr}$ ) in breccia cement aluminosilicates (Al-Si Brk); $d$ scheelite compact (Sh) with perovskite (Prv) in calcite-quartz breccia cement (Ca-Si Brk); e-monocyte (Mz) in calcite-quartz breccia cement (Cal-Si Brk); f-tetradymite (Td) in pyrite (Py) 
orite-plagiogranite composition (the Kunush complex $\mathrm{C}_{3}$ ) is productive for gold mineralization in the West Kalbinsk zone. The gold-sulphide mineralization zones and gold ore objects of various geological and industrial types (Bakyrchik, Suzdal, Kulujun, and others) are associated with them, as can be seen from Fig. 1. The rare-metal mineralization of the superimposed type (Fig. 1) - Ta, Nb, Li, Sn, W, and so on is manifested in the Kalba Narymsky zone in plagiogranites and dykes of the Kunush complex subject to metasomatic transformations under the influence of the Perm intrusive magmatism of the Kalba-Narym pluton (Medvedka, Tochka, Cherdoyak, Shiykol and others).

The post-collisional (orogenic) intraplate geodynamic setting was marked by a powerful development of Permian granitoid magmatism with rare metal metallogenic specialization: the Kalba granite complex $\mathrm{P}_{1}(\mathrm{Ta}, \mathrm{Nb}, \mathrm{Li}, \mathrm{Sn}, \mathrm{Cs}, \mathrm{W})$; Monastyrsky leucogranite (TR, W, chambered crystal-bearing pegmatites); Delbegetey granite-leukograngite complex $\mathrm{P}_{2}$ ( $\mathrm{Sn}, \mathrm{Be})$; the Buran monzonite-syenite-alkaline-granite $\mathrm{P}_{2}$ $(\mathrm{Ti}, \mathrm{Zr})$ and the Miryubovsky dike gabbro-diabase-graniteporphyritic $\mathrm{P}_{2}$ (Ta, $\mathrm{Li}, \mathrm{Sn}$ ) complexes.

At the same time, the Kalbinsk complex granitoids of phase I have a pronounced increased basicity and are productive for the leading type (tantalum-tin-lithium-cesium rare metal-pegmatite) mineralization (Bukennoe, Yubileynoye, Belaya Gora deposits, etc.).

Quartz-albite-muscovite pegmatites and albite-greisen metasomatites $\mathrm{Sn}, \mathrm{Ta}$, Li (Quartz), as well as greisenquartz-vein deposits (Leninskoe, Karash, and others) are associated with granites of phase II of this complex. Wolframite hydrothermalites and monazite placers are characteristic for the Monastyrsky leucogranites. The Buran granitoids are productive for zircon-ilmenite mineralization in residual weathering crusts and alluvial deposits (Satpayevskoe, and so on).

Conclusions. The studies have shown that a lot of deposits can be considered as complex ones, due to peculiarities of ore formation processes and different mineralization types. Gold and rare metal mineralization of different stages have been found within large ore control structures of ore fields at the known deposits. It has been found out that complex mineralization is within long-lived ore control structures (shear zones, zones of crossing differently directed deep-level tectonic faults, ring-type structures, deep-level intrusions, and others). There are perspectives of recovering rare and rare earth elements together with gold from gold containing ores at some of them. First of all, it is Bakyrchik big ore cluster in East Kazakhstan, which is connected with Kyzyl shear zone genesis. Gold deposits in Bakyrchic and other black-shale rock mass (W, Mo, As, Sb, Pt, REE, and so on) are associated with this shear zone. Some gold-sulphide-quartz stockwork deposits of Sekisovskoe are of significant interest in rare metals and rare earths (W, Mo, Bi, Co, Sn, Rb, Pt and others).

In its turn, the study of the proper rare metal deposits shows high content of precious metals, radioactive elements and rare earths. Certainly, this facilitates attention to studying the similar deposits as complex objects.

So called extra-pegmatites of rare metal mineralization for $\mathrm{Nb}, \mathrm{Li}, \mathrm{Sn}$ can serve as additional sources of rare metals along with traditional sources in the Kalba-Narym zone. Also rare metal-pegmatite ores $\mathrm{Li}, \mathrm{Ta}, \mathrm{Nb}$ and greisen-quartz-veined ore Sn,W deserve the attention. Defined potential ore content of Kalba granitoids formation types can be the base for scientific forecast and geological exploration practice. The further study of rare metal mineralization at gold-sulphide stockwork deposits of the Rudny Altai and West Kalba is required as well as the study on tungsten mineralization at black-shale deposits.

Acknowledgements. The work was performed within the framework of MES RK grant financing, project 36-26-18 APO5131489.

\section{References.}

1. Rafailovich, M. S. (2013). Geology of Central Asian gold: ore evolution, metasomatic formations, explosive breccia. Monograph, Almaty. ISBN978-601-289-107-2.

2. Kuzmin, M.I., Yarmolyuk, V.V., \& Kotov, A. B. (2018). Early evolution of the Earth, beginning of its geological history: how and when granitoid magma appeared. Litosphera, 5, 653-371. https://doi.org/10.24930/1681-9004-2018-18-5653-671.

3. Potseluev, A. A. (2014). Precious metals ore in hydrothermal uranium and rare metal deposits of Central Asia. Monograph. Tomsk: STT. Retrieved from http://www.geokniga.org/bookfiles/geokniga-blagorod nometallnoe-orudenenie-v-gidrotermalnyh-uranovyh-i-redkometallny.pdf.

4. Dittrich, T., Seifert, T., Schulz, B., Hagemann, S., Gerdes, A., \& Pfänder, J. (2019). Archean Rare-Metal Pegmatites in Zimbabwe and Western Australia. Geology and Metallogeny of Pollucite Mineralisations. Springer International Publishing. https://doi.org/10.1007/978-3-030-10943-1.

5. Mizernaya, M.A., Miroshnikova, A. P., Pyatkova, A. P., \& Akylbaeva, A. T. (2019). The main geological-industrial types of gold deposits in East Kazakhstan. Naukovyi Visnyk Natsionalnoho Hirnychoho Universytetu, (5), 5-11. https://doi. org/10.29202/nvngu/2019-5/2.

6. Alexander P. Gysi, Anthony E. Williams-Jones, \& Patrickn (2016). Collins Lithogeochemical Vectors for Hydrothermal Processes in the Strange Lake Peralkaline Granitic REE-Zr$\mathrm{Nb}$ Deposit. Economic Geology, 11, 1241-1276. https://doi. org/10.2113/econgeo.111.5.1223.

7. Mikhailova, J.A., Pakhomovsky, Ya.A., Ivanyuk, G. Yu., Bazai, A. V., Yakovenchuk, V.N., Elizarova, I. R., \& Kalashnikov, A. O. (2017). REE mineralogy and geochemistry of the Western Keivy peralkaline granite massif, Kola Peninsula, Russia. Ore Geology Reviews, (82), 181-197. https://doi.org/ 10.1016/i.oregeorev.2016.11.006.

8. Baisalova, A. O., Dolgopolova, A. V., Seltmann, R., Stepanov, A.V., \& Bekenova, G.K. (2017). Variations of chemical composition of gagarinite from the Verkhnee Espe deposit, as indicator of mineral forming conditions and position in metasomatic column. News of the National Academy of the Republic of Kazakhstan. Series of Geology and Technical Sciences, 2, 37-45. 9. Mizernaya, M., Dyachkov, B., Kusmina, O., Mizerny, A., \& Oitseva, T. (2017). Main types of gold deposits of the eastern Kazakhstan. International Multidisciplinary Scientific GeoConference Surveying Geology and Mining Ecology Management, SGEM, Albena; Bulgaria, 17(11), 299-306. https://doi. org/10.5593/sgem2017/11/s01.038.

10. Beskin, S. M., \& Marin, Yu. B. (2019). Peculiarities of granite systems with rare metal pegmatites. Zapiski Rossiyskogo mineralogicheskogo obshchestva, 148(4), 1-16. https://doi. org/10.30695/zrmo/2019.1484.00.

11. Annikova, I. Yu., Vladimirov, A. G., Smirnov, S.Z., \& Gavryushkina, O.A. (2016). Geology and mineralogy of the Alakha Spodumene Granite Porphyry Deposit, Gorny Altai, Russia. Geology of Ore Deposits, 58(5), 404-426. https://doi. org/10.1134/S1075701516050020.

12. Khromykh, S. V., Tsygankov, A.A., Kotler, P.D., Navozov, O. V., Kruk, N. N., Vladimirov, A. G., Travin, A. V., ... \& Karavaeva, G. S. (2016). Late Paleozoic granitoidmagmatism of Eastern Kazakhstan and Western Transbaikalia: Plume model test. Russian Geology and Geophysics, 57(5), 773-789. https://doi.org/10.1016/j.rgg.2015.09.018.

13. Kotler, P. D., Khromykh, S.V., Vladimirov, A. G., Navozov, O.V., Travin, A.V., Karavaeva, G.S., Kruk, N.N., \& Murzintsev, N.G. (2015). New data on the age and geodynamic interpretation of the Kalba-Narym granitic batholith, eastern Kazakhstan. Doklady Earth Sciences, 462(2), 565-569. https://doi.org/10.1134/S1028334X15060136.

14. Mizerny, A. I., Miroshnikova, A. P., Mizernaya, M. O., \& Diachkov, B. O. (2017). Geological and structural features, magmatism and mineralization of Sekysivske and Vasylkivske 
Stockwork gold deposits (Kazakhstan). Naukovyi Visnyk Natsionalnoho Hirnychoho Universytetu, (2), 5-13.

15. Yarmolyuk, V. V., Lykhin, D. A., \& Kozlovsky, A. M. (2016). Composition, sources, and mechanisms of rare metal granitoids formation of Late Paleozoic East-Sayan zone of alkaline magmatism (on the example of Ulan-Tologai massif). Petrologiya, 24(5), 515-536. https://doi.org/10.7868/S0869590316050083.

\section{Геохімічна характеристика та металогенія герцинських гранітоїдних комплексів (Східний Казахстан)}

\author{
М. О. Мізерна ${ }^{1}$, С. С. Айтбаєва ${ }^{1}$, А. I. Мізерний ${ }^{1}$, \\ Б. О.Д'ячков ${ }^{2}$, А. П. Мірошникова ${ }^{3}$
}

1 - Східно-Казахстанський державний технічний університет імені Д.Серікбаєва, м. Усть-Каменогорськ, Республіка Казахстан, e-mail: mizernaya58@bk.ru

2 - ТОВ «Алтайський геолого-екологічний інститут», м. Усть-Каменогорськ, Республіка Казахстан, е-mail: bdyachkov@mail.ru

3 - Філія РГП «НЦ КПМС РК» «ВНИИцветмет», м. Усть-Каменогорськ, Республіка Казахстан, е-mail: anastasiya-2588@mail.ru

Мета. 3'ясування закономірностей формування та просторового розподілу нових нетрадиційних видів мінералізації рідкісних металів, розробка критеріїв прогнозування та пошуку, оцінка перспектив в якості додаткового резерву для зміцнення й розвитку мінерально-сировинної бази Східного Казахстану.

Методика. Методами ICP MS у Центрі випереджаючого розвитку ВКГТУ імені Д. Серікбаєва вивчені традиційні й нетрадиційні родовища та прояви рідкіснометального зруденіння в межах Західної Калби та Рудного Алтаю, магматити рідкіснометального Калба-Наримського гранітоїдного пояса. Проведене вивчення хімічного складу магматитів ряду інтрузивних комплексів, встановлено зв'язок гранітоїдів із родовищами та проявами рідкісних металів. Методами скануючої електронної мікроскопії (JSM 6390LV) проведена порівняльна характеристика рудної мінералізації досліджуваних родовищ.

Результати. У межах пермського гранітоїдного КалбаНаримського пояса (Східний Казахстан) виділені магматичні комплекси, перспективні на різні типи редкіснометального зруденіння, зроблені висновки щодо зв'язку потенційної рудоносності з певними формаційними типами гранітів.

Наукова новизна. Встановлено, шо поряд із традиційним рідкіснометальним типом у межах Калба-Наримського металогенічного пояса виявлені внепегматітові нетрадиційні прояви рідкіснометальної мінералізації $\mathrm{Nb}$, $\mathrm{Li}, \mathrm{Sn}$. Перспективними є також рідкіснометально-пегматитові руди з підвищеним вмістом $\mathrm{Li}, \mathrm{Ta}, \mathrm{Nb}$, а також грейзено-кварцовожільні прояви $\mathrm{Sn}, \mathrm{W}$, а також золоторудні об'єкти з підвищеним вмістом рідкісних елементів. Встановлено підвищений вміст рідкісних металів і рідкісних земель у рудах золоторудних родовищ Західної Калби та Рудного Алтаю.

Практична значимість. Отримані дані можуть бути використані при проведенні прогнозу й пошуків родовищ рідкісних металів і комплексних золото-рідкіснометальних об'єктів.

Ключові слова: гериинський магматизм, родовища, рідкісні метали, Калба-Наримський рідкіснометальний пояс, Казахстан, ресурси

\section{Геохимическая характеристика \\ и металлогения герцинских гранитоидных комплексов (Восточный Казахстан)}

М.А. Мизерная ${ }^{1}$, С. С. Айтбаева ${ }^{1}$, А. И. Мизерный', Б. А. Дьячков ${ }^{2}$, А. П. Мирошникова ${ }^{3}$

1 - Восточно-Казахстанский государственный технический университет имени Д.Серикбаева, г. УстьКаменогорск, Республика Казахстан, e-mail: mizernaya58@ $\underline{\text { bk.ru }}$

2 - ТОО «Алтайский геолого-экологический институт», г. Усть-Каменогорск, Республика Казахстан, e-mail: bdyachkov@mail.ru

3 - Филиал РГП «НЦ КПМС РК» «ВНИИцветмет», г. Усть-Каменогорск, Республика Казахстан, e-mail: anastasiya-2588@mail.ru

Цель. Выяснение закономерностей формирования и пространственного распределения новых нетрадиционных видов минерализации редких металлов, разработка критериев прогнозирования и поиска, оценка перспектив в качестве дополнительного резерва для укрепления и развития минерально-сырьевой базы Восточного Казахстана.

Методика. Методами ICP MS в Центре опережающего развития ВКГТУ имени Д. Серикбаева изучены традиционные и нетрадиционные месторождения и проявления редкометального оруденения в пределах Западной Калбы и Рудного Алтая, магматиты редкометального Калба-Нарымского гранитоидного пояса. Проведено изучение химического состава магматитов ряда интрузивных комплексов, установлена связь гранитоидов с месторождениями и проявлениями редких металлов. Методами сканирующей электронной микроскопии (JSM 6390LV) проведена сравнительная характеристика рудной минерализации изучаемых месторождений.

Результаты. В пределах пермского гранитоидного Калба-Нарымского пояса (Восточный Казахстан) выделены магматические комплексы, перспективные на различные типы редкометального оруденения, сделаны выводы о связи потенциальной рудоносности с определенными формационными типами гранитов.

Научная новизна. Установлено, что наряду с традиционным редкометальным типом в пределах Калба-Нарымского металлогенического пояса обнаружены внепегматитовые нетрадиционные проявления редкометальной минерализации $\mathrm{Nb}, \mathrm{Li}, \mathrm{Sn}$. Перспективными являются также редкометально-пегматитовые руды с повышенным содержанием $\mathrm{Li}, \mathrm{Ta}, \mathrm{Nb}$, а также грейзеновкварцевожильные проявления Sn, W, а также золоторудные объекты с повышенным содержанием редких элементов. Установлены повышенные содержания редких металлов и редких земель в рудах золоторудных месторождений Западной Калбы и Рудного Алтая.

Практическая значимость. Полученные данные могут быть использованы при проведении прогноза и поисков месторождений редких металлов и комплексных золоторедкометальных объектов.

Ключевые слова: гериинский магматизм, месторождения, редкие металлы, Калба-Нарымский редкометальный пояс, Казахстан, ресурсы

Recommended for publication by Ye. M. Sapargaliyev, Doctor of Geological and Mineralogical Sciences. The manuscript was submitted 12.04.19. 